\title{
The accusation of 'world disturbers' (Acts 17:6) in socio-political context
}

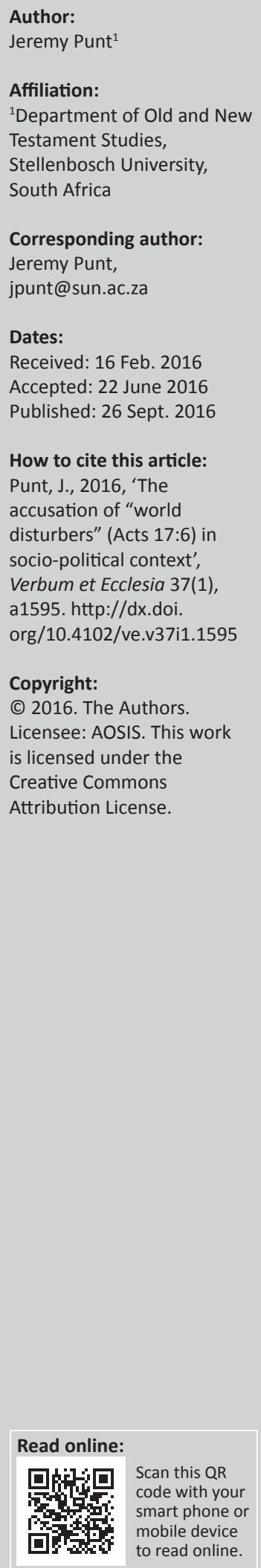

Acts 17:1-9 presents a narrative of the consequences of Paul's engagements in Thessalonica's synagogue. Following Paul and Silas' reported successful 3-week mission, some Jews hauled Paul and Silas' host, Jason, and a number of Jesus followers before the authorities. The threefold accusation was that Paul and Silas turned the world upside down, acted against Caesar's decrees and claimed another king, Jesus. This incident is investigated from the perspective of Acts' presentation of competing missions, in the context of the intersectionality of religion and politics in the 1st century $\mathrm{CE}$. The article challenges a narrow theological interpretation of Acts 17, insisting on the need for and value of a socio-political interpretive lens to make sense of the rhetoric of this chapter.

Intradisciplinary and/or interdisciplinary implications: The article challenges a narrow theological interpretation of Acts 17, insisting on the need for and value of a socio-political interpretive lens to make sense of the rhetoric of this chapter.

\section{Introduction}

Acts 17:1-9 narrates the consequences of Paul and Silas' engagements among Thessalonica's Jewish community. Following a reportedly successful 3-week mission, some Jews hauled Paul and Silas' host, Jason, and a number of Jesus followers before the authorities. The threefold accusation was that they turned the world upside down, acted against Caesar's decrees and claimed another king, Jesus. This article investigates these claims from the perspective that Acts presents competing missions ${ }^{1}$ (cf. Punt 2015:89-106), in the context of the intersectionality of religion and politics in 1st century CE. And as Vaage (2006:278) has recently suggested, 'earliest Christianity's intrinsic will to rule is most evident, albeit paradoxically, in its initial modes of resistance to this regime'. The suggested anti-imperial stance of early Jesus followers and accompanying (and maybe deliberate) ambiguity in the negotiation of the Empire as reflected in Acts frame the following discussion.

\section{Acts and the Empire}

Often seen as part of a double work with Luke's Gospel, ${ }^{2}$ Acts is a narrative on the Jesus followers, focussing on Peter and Paul. ${ }^{3}$ Its rhetoric details the emerging church ${ }^{4}$ as part of the spread of the gospel of Jesus Christ (cf. Bryan 2005:95-105; Walton 2008:74). ${ }^{5}$ Luke-Acts interacts more explicitly with its political context than most other New Testament writings. In Luke, and to an extent contrary to the other gospel writers, Jesus' story features the political context and circumstances

1.Although Rowe (2009:5) probably means his comment that "Luke narrates the threat of the Christian mission in such a way as to eliminate the possibility of conceiving it as in direct competition with the Roman state' at the level of political power, my argument is situated at the ideological level.

2.The long-held consensus, amidst some opposition, that Luke and Acts are two parts of a double work provides the backdrop to this paper. The question whether the Empire is portrayed in the same way in both parts of Luke-Acts is not addressed here; suffice it to refer to feminist concerns that point to different portrayals of women in the two parts, with women in Acts increasingly silenced although the believing community's boundaries are extended beyond Jesus' family-like audiences to the public sphere of a man's world (e.g. Seim 2004).

3.The focus of this contribution is the Paul as depicted in Acts; no claims to the 'real Paul' are made here.

4.'Church' is collective shorthand for multiple and diverse Jesus-follower communities of the middle to late 1st century CE, as suggested in Acts; no unitary, normative ecclesial structure either in Acts or during the 1st century CE is implied or suggested. However, the use of 'Christian' twice (Acts 11:26; 26:28) suggests interest in tracing originating aspects of incipient early Christianity (cf. Taylor 1994:75-94) although the Jesus-follower communities were still deemed a sect or 'reform' movement within the Judaism of the time (cf. Spencer 2005:113 n28)

5.Walton (2008:74-76) provides a brief overview of important shifts in the history of Acts' interpretation of Acts: the early commentary of Chrysostom related it to contemporary Christian life and faith; the 19th century missionary movement saw in Acts a charter document for Christian mission; historical-critical studies, and redaction criticism in particular, with a decided history of religious focus, was replaced with a focus on the 'delay of the parousia' in Luke-Acts (prefigured in Conzelmann's [1960] three-fold understanding of the unfolding 'history' of the church in Luke-Acts - Heilsgeschichte - replacing the early church expectation of an imminent end: time before Jesus' birth; Jesus' ministry; and the church era [Lk 16:16]); and since the 1980s narrative criticism focused on the text's final form.

Note: Edited version of a paper read at a mini-conference on 'Acts 17 and Contextual Issues', Pretoria, 07-09 December 2015. 
of 1st century Judea. References include local and central authorities like the name Herod, king of Judea (Luke 1:5); Pontius Pilate, governor of Judea (Luke 3:1-2); and Caesar Augustus (Luke 2:1-2) in Rome. Already the gospel emphasises the emperor of Rome's influence in a region where the Herodians as Jewish-Edomite dynasty greatly benefited; references to the census and Roman governor of Syria related to the exercise of power through tax practices and a threatening military presence on Judean boundaries (Burrus 2007:134; cf. Cassidy 1978).

Following suit, Acts makes more direct references to the 1st-century world of the Empire than any other New Testament (NT) document. In this complex document with its numerous dimensions borne out in specific geographical and historical settings, our focus ties in with its overt and subtle imperial context. Acts mentions numerous imperialrelated matters (cf. Gilbert 2003:237): five of the seven references to 'P $\omega \mu \eta$ [Rome] are found in Acts (18:2; 19:21; $23: 11 ; 28: 14 ; 28: 16)$, as are 11 of the 12 uses of the adjective

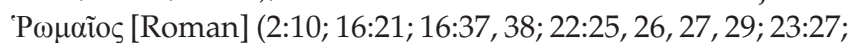
$25: 16 ; 28: 17)$ and 18 of the 29 designations Kaĩo $\rho$. In addition, in the NT, only Luke-Acts mentions names of Caesars: Augustus (Lk 2:1), Tiberius (Lk 3:1) and Claudius (Ac 11:28; 18:2). References to the Empire, although helpful in making the imperial context explicit, are indicative of sustained ideological engagement between the text and its political social location.

Three broad, often contradictory but never fully absent intersecting interpretive lines indicate - even if they do not encompass - the intricacy of the narrative of Acts. The lines illustrate the ambivalence of sociocultural frames in the story of Acts. In the first place, for Acts, the traditions of Israel are not redundant. In fact, there is a conscious effort to connect the early followers of Jesus with the traditions and ancestors of Israel, as evidenced in Acts 3:13; 5:30; 15:10; 22:14; $26: 6$ and 28:25, as signalled already in Luke 1 . In the second place, and without contradiction with the previous, Acts at the same time emphasised the compatibility of faith in Christ with loyalty to the Roman Empire (Esler 1987:201-219; cf. Walton 2004:249). At a third and further level of distinction, the story of apparent integration of Jesus' followers into imperial designs and structures such as the patronage system (Ac 12; $16 ; 18$ ), the judiciary (Ac 21-26) and even friendship towards Roman officials or support of the urban elite (e.g. Ac 13:12; 17:4) show the complexity and subtlety of politics in imperial times, even where the (imperial) system is seemingly tolerated or confirmed (see Burrus 2007:134-144). ${ }^{6}$

Luke-Acts' interest in the Roman Empire has rendered different explanations, covering a range of opinions, from seeing the work as a Christian apologetic to the Roman authorities, to a Roman apologetic towards incipient Christian communities, and many variations in between. Luke-Acts can be described as more pro-Roman Empire than

6.Gilbert (2003:236) bemoans the fact that although scholars have mined Jewish Greek and Latin resources to make sense of Luke-Acts, very little attention has been given to the role of political propaganda. any of the rest of the New Testament (Alexander 1991:15), with Roman authority usually affirmed (Hollingshead 1998:xii). The traditional view on Luke-Acts sees this work as accommodating of the Empire, presenting the communities of Jesus followers as being no political threat to imperial power and politics. Luke-Acts is seen to offer legitimation ${ }^{7}$ for the faith of the early Jesus followers (e.g. Esler 1987), or faith's compatibility with loyalty to the Empire. Others argue that Acts sought recognition for the new religious grouping to ensure its status as religio licita and accompanying benefits and privileges (Walton 2004:248). As alternative accommodationist interpretation, Acts has been construed as an apology for the Empire to the followers of Jesus ${ }^{8}$ (Walaskay 1983; cf. Walton 2004:248). ${ }^{9}$ Engagement with Acts' narrative conscious about its complexities sets the scene for diverging positions and for recognising the Luke-Act's ambivalence towards the Empire, as interventionist literature addressing the intersection of emerging Christian and imperial concerns. However, the common element shared by different investigative approaches is recognition of the significance of the Empire in Acts. ${ }^{10}$ Notwithstanding such a wide spectrum of interpretive opinion, the ambiguity of Acts' relationship to the Empire (e g Cassidy 1978) generally has not received much attention. ${ }^{11}$

Finally, before turning to Acts 17:1-9, the division between theory and history as two approaches to evaluating texts regarding the stance towards the Empire (Smith 2010:305-310) is misleading. Historical analysis is not devoid of theory nor does theory necessarily treat history as incidental. ${ }^{12}$

\footnotetext{
7.Esler argues that this was no mere ecclesial-apologetic but that Acts sanctioned the social move of those who associated with an old order (even Roman soldiers or administrators, e.g. Ac 10:1-11:18; 13:6-12; 18:7), with accompanying bonds and commitments, to joining a new order with accompanying motivation and legitimation. It entailed appreciation for the Israelite ancestry of the church (Ac $3: 13 ; 5: 30 ; 15: 10 ; 22: 14 ; 26: 6 ; 28: 25$ ) and affirmation for the antiquity and therefore credibility of faith in Christ (Esler 1987:1-23, 201-219; cf. Bryan 2005:96). However, Walton is worried about Esler's mirror-reading identification of Acts' audience (Walton 2004:249). Dunn (1993:7) points to Luke-Act's general tendency to draw 'a veil over most of the discord and disunity which racked much of the early expansion of Christianity'.
}

8.Some scholars (e.g. Walton 2004:248-249) challenge the consensus that titles used for Jesus such as 'Lord' (кúploc) would have been in conflict with Caesar's similar claim, based on the (Kupsence of rhetorical attacks on the Roman Empire such as found in other Second Temple Jewish writings (e.g. 4 Ezra; Sibylline Oracles; such as found in other Second Temple Jewish writings (e.g. 4 Ezra; Sibylline Oracles;
Revelation), and claim that Luke simply situated the early Christian church in its imperial context (Lk 2:1-5; 3:10-14).

9.Options other than seeing Luke-Acts as political apology on behalf of the church addressed to supporters of Rome or apology on behalf of Rome addressed to the church include legitimation for the church's identity; equipping the churches to live in the Roman Empire; Luke-Act's political disinterest (Walton 2002:2-12) in favour of a theological focus showing God's actions in Christ as integral to God's faithfulness to his promises to Israel (e.g. LT Johnson, J Jervell in Bryan 2005.95) and preparation of his audience for their impending suffering for their faith under and preparation of his audience for their impending suffering for their faith under the Empire or otherwise (e.g. Cassidy). Political rationalisations of course did no ule out intra-Jewish identity concerns about whom or what constituted 'true Israel', the sins that required repentance and the accommodation and role of
gentiles in God's salvation and judgement (Tiede 1988:328).

10.One scholar even offers a differentiated, threefold purpose for Acts' attitude towards the Empire: communicating the author's faith in Jesus, offering guidance to fellow believers on life under Roman rule and providing direction and support for believers who may end up in a trial before Roman authorities (Cassidy 1978; cf. Neagoe 2004:215). In fact, some argue that Acts presented some scripted scenarios of imperial attitudes towards the followers of Jesus, presenting believers with guidance on how to act in similar situations (cf. Walton 2004:248-249; Punt 2015:89-106).

11.Notwithstanding his cooperation with the authorities, the portrayal of Paul's involvement in social disturbances challenged his loyalty to the Empire (e.g. Ac $24: 25 ; 25: 10-11 ; 28: 19)$. The ambiguities in the text and ambivalence of its $24: 25 ; 25: 10-11 ; 28: 19)$. The ambiguities in the text and ambivalence of its
portrayals are not directly related to authorial intent, since the rhetorical structures portrayals are not directly related to auth
of the text receive primary attention.

12.Smith (2010:321) appears to confuse postcolonial theory that entertains ambivalence, hybridity and imperialism as hegemony, to name a few central 
Reductionist scholarly work (e.g. Kim 2008; cf. Smith 2010:321) is to be avoided, such as when the Empire primarily becomes a matter of structures and systems, and, at that, fairly monolithic and universal across the 1st century. ${ }^{13}$ The multiple levels and dimensions in Acts, referred to above, complicate its interpretation and require nuanced theoretical considerations and historical investigations beyond bland anti- or pro-Empire positions also in accounting for Acts' stance on socio-political matters generally and portrayal of the current imperial context specifically. Given these considerations, our attention turns to Acts $17: 1-9$.

\section{Acts 17:1-9}

The basic accusation levelled against Acts' portrayal of Paul and his compatriots, that they were disturbing the world, fits into the larger perspective of Acts which depicts a God at odds with the establishment through changing people's lives and societal conventions (Skinner 2015). ${ }^{14}$ So important was loyalty to the empire and the emperor considered since early in the 1st century, and especially since Tiberius' reign (AD 14-37), that delatores and accusatores informed on and accused those whose loyalty was considered not in place (Rutledge 2001:3). Delatores and accusatores under the early emperors were not simply instruments of tyranny such as contemporary sources often portrayed them. The ethos and social forces which elicited action on their side included factors like personal enmity (inimicitia) - a significant factor in prosecutions throughout the Principate; a sense of duty towards one's friends or family (pietas); the client-patron 'system'; and the desire for political and social clout and authority (auctoritas and dignitas). ${ }^{15}$ These factors were entrenched in Roman society in early imperial times, as much as other social prejudices and ethical reservations which brought about the negative depiction of delatores in the source materials. More than being early forms of spying out possible subversives in the community or instigating legal process against those considered culpable, delatores and accusatores reflected enduring cultural and political values in Roman

(footnote 12 continues...)

notions, with a rigid and narrow anti-imperialism, poised on us-versus-them binaries. Proper investigation of the reach and ambit of postcolonial work could have enhanced Smith's investigation, and could have aided him in omitting his onesided and inaccurate portrayals of the materials he reviewed. See also Cline and Graham (2011:5-7): theory helps to make sense of fragmented history and sources.

13.It remains ironical that Smith (2010:305-322), for all his willingness to concede the varied roles of Emperors in the Roman Empire, seems to conjure up a rather uniform face of the Empire as it manifested in different geographical and temporal locations. The extent to which Smith has bought into scholarly Romanisation is evident when he claims, 'Roman administration is simply a necessary framework evident when he claims, 'Roman administration is simply a necessary frame
for an ordered and relatively secure life' (Smith 2010:321, emphasis added).

14.The charges brought against Paul and Silas in their absence in Thessalonica largely correspond to the charges levelled against them in Acts 16:20-21: causing socia

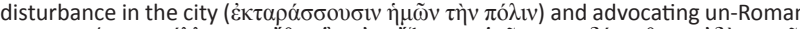

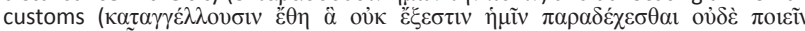

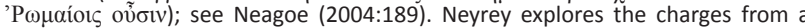
Jewish perspective and focussing on purity ('the basic sense of order and placement') concerns and its related boundaries, noting that similar accusations against Jesus followers are found in, for example, Acts $6: 13-14 ; 21: 21 ; 21: 28$ (Neyrey 1991:271-304)

15.Rutledge (2001:4) argues that the changed environment of the Principate contributed to delatores activity: 'the princeps' (i.e. emperor's) assumption of patronage, the need to protect his person, dynastic politics, a superabundance of new legislation, new legal prerogatives bestowed on the senate along with a new legislation, new legal prerogatives bestowed on the sen
changing set of demographics in that body and other factors'. society at the time. ${ }^{16}$ Such values appear also to inform - at least partially - the narrative of Paul and Silas' trial in absentia in Acts 17.

According to Acts 17:1-9, Paul and Silas visited Thessalonica, successfully, since some Jews, devout Greeks and prominent women ${ }^{17}$ joined them ( $\Sigma 1 \lambda \tilde{\alpha}, 17: 4)$. However, according to Acts, resistance against

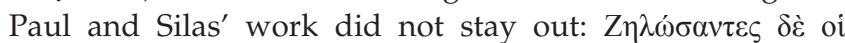

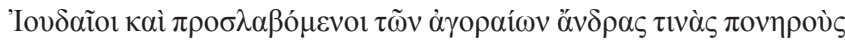

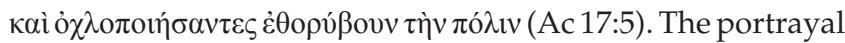
of Jews in Acts requires further attention which is not possible here. In the narrative, however, some Jews serve as both delatores and accusatores of Paul and those associated with him, indicating intra-Jewish jealousy as the cause of charging Paul and Silas' friends before the courts. With

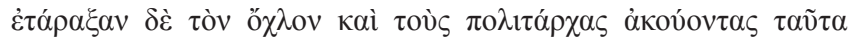
(17:8) Acts scripts not only the crowd's unsettlement but also that of the politarchs or civic magistrates. ${ }^{18}$ Indeed, one responsibility of local officials in the eastern Mediterranean was to enforce loyalty to Caesar (cf. Keener 1993:375), and the accusations levelled against Paul and Silas threatened such allegiance. More important than the mechanisms of the accusations is the specific content of the charges raised against Paul and his compatriots. ${ }^{19}$

\section{Accusation 1: Turning the world upside down}

Acts holds that after Paul's brief imprisonment in Philippi, which also resulted from charges that he was involved in anti-Roman sedition (Ac 16:21), he was soon again accused of the same in Thessalonica (Ac 17:7). ${ }^{20}$ The first accusation levelled against Paul and Silas in Acts 17 was that they have upset the world, or as some translations (e.g. RSV) would

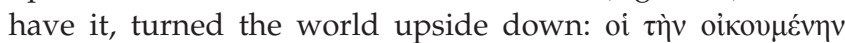

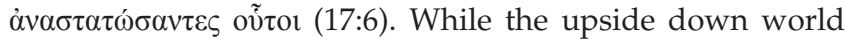
translation could conjure up an inversus mundus theme, used from time to time in the $\mathrm{HB} / \mathrm{OT}$ and also in the contemporary 1st-century world, more seems to be at stake here. The accusation of turning the world on its head went directly against imperial claims upon neatly ordered geopolitical space, and its world conquest in the form of a singular and

16.The situation is further complicated since the delator was as much a rhetorical construct as a historical phenomenon (cf. Rutledge 2001:5)

17.'Macedonian women had earlier gained a reputation for their influence, which they probably still exercised in this period. As patrons within the church or synagogue, upper-class women could also enjoy higher status than was available to them in society at large due to their gender. Social conditions thus made it easier for well-to-do women than for men to convert' (Keener 1993:374).

18.Acts used the precise designation for Thessalonica's city officials, namely 'politarchs' (also v. 6), which was a term almost exclusive to Macedonia. In the middle of the 1st century CE, they were between five or six in number, and were politically in charge of Thessalonica although they were answerable to Rome (Keener 1993:374). The magistrates' dual role as functionaries of state order but also guardians of the prescribed religious rites and ceremonies probably informs Acts' references to them.

19.Acts treatment of the accusations is laced with irony: 'the charge of social disturbance is introduced by an avalanche of terminology indicating the prosecutors' own social misbehaviour (17.5-6), while the political concern with Caesar's decrees and kingship hardly looks appropriate coming from a Jewish group. In addition, both charges are undermined by the jealousy which motivates them (17.5a)' (Neagoe 2004:191).

20.As far as Acts is concerned, Paul's 'long imprisonment in Caesarea was due to the political intrigues of various Roman officials who were responsible for determining whether Paul had been guilty of the same crime in Jerusalem (cf. Ac 23:28-29, 25:8-9, 18-19; 26:31)' (White 2009:306). 
matching order imposed upon various peoples in different parts of the world. ${ }^{21}$ Imperial ideology dictated a vision of a world subservient to the Empire, remaking history and so formatting the cosmos for the Empire's sake (Punt 2013) deemed to be threatened by Paul and Silas' work.

Paul and Silas are accused of political anarchy, subversion or resistance of one form or another. This accusation forms part of an ambivalent context as far as the interaction between Paul and his associates, and the imperial (-aligned) functionaries or agents was concerned. On the one hand, neutral and even supportive attitudes of Roman officials towards the apostles of Christ in Acts include incidents of a town clerk pacifying labour-related turmoil ( $\theta$ ópvßov; Ac 20:1) among the Artemis-traders in Ephesus (Ac 19:35-40), claiming, among others, that Gaius and Aristarchus (Paul's companions) were 'neither sacrilegious nor blasphemers of

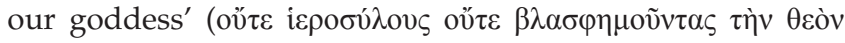
$\eta \tilde{\mu} \tilde{v}$; 19:37), to governors Felix ${ }^{22}$ and Festus who attributed Jewish antipathy towards Paul and his compatriots to intraJewish disputes and minor concerns (e.g. Ac 24:22; 25:19). Then also Festus approved of Paul's appeal to Caesar (Ac 25:9-12), and the Roman centurion of Paul's military escort decided against killing the prisoners when their ship is lost at sea, because he wanted to spare Paul's life (Ac 27:43). Also in the conversion stories, Roman functionaries and soldiers were included; the centurion Cornelius's conversion through Peter (Ac 10-12) and the conversion of the pro-consul Sergei Paulus (Cyprus) (Ac 13:12) and the prison guard in Acts 16 are probably among the best known. In Acts 17, Paul and Silas' host, Jason, is held responsible for their actions, having to post a bond for them; although a lenient penalty in Roman courts, a bond to curtail troublemakers was not unusual. ${ }^{23}$

On the other hand, Acts also details tension and even conflict between imperial agents and Jesus followers, at least in a few respects. One, the arrest, imprisonment and punishment of the followers of Christ were conducted by the Empire's political and military functionaries ${ }^{24}$; two, the imperial source provided authority and power to the Jewish vassal kings and other local authorities ${ }^{25}$; and, three, their relationship with

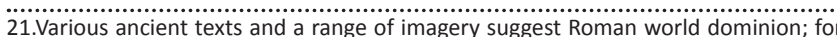
example, Augustus' Res Gestae; Polybius (Histories 1.7-9) suggests that in Rome the history of the world unites into a universal history; or re-imagery of the oikoumenē on Augustus' Prima Porta statue and goddess Roma sitting astride globe as symbol of universal domination; see, for example, Gilbert (2003:247-253) and Quint $(1989 \cdot 10)$. Rowe $(2009 \cdot 5)$ acknowledges the 'mission into the gentile world as a collision with culture-constructing aspects of that world' but gives hardly any attention to the Empire's vested interest in this regard.

22. Hoping and waiting for a bribe, Felix is said to have often summoned and conversed with Paul (Ac 24:26) - whether because of fear of Paul or regarding him a dangerous person remains unclear in the way Felix's interactions with Paul is reported.

23.Given the nature of the charges against them (Ac 17:7), had Paul and Silas been caught, they might not have been so fortunate (Keener 1993:375)

24.The numerous trials in Acts, besides Jesus Christ's trial in Luke 22-23, include those in Acts: 4:3-23 (Peter and others; in Jerusalem); Acts 5:17-40 (Peter and others; in Jerusalem); Acts 6:9-7:60 (Stephan; in Jerusalem); Acts 16:19-36 (Paul and Silas; in Philippi); Acts 17:5-9 (Paul and others; in Thessalonica); Acts 18:12-17 (Paul; in Corinth); Acts 21:27-22:30 (Paul; in Jerusalem); Acts 22:30-23:10 (Paul; in Caesarea); Acts 24:1-26 (Paul; in Caesarea); Acts 25:5-12 (Paul; in Caesarea); Acts 25:24-26:32 (Paul; in Caesarea); and Acts 28 (Paul; in Rome). See Malina and Neyrey (1991:121) and Neagoe (2004).

25.Acts lays the blame for many of the fiercest actions in Acts before the door of the Jewish king Herod Agrippa I: he had James brother of John killed by the sword (Acts 12:2); had Peter arrested, during the festival of Unleavened Bread (Acts 12:3), and executed two guards who reported Peter's freeing from incarceration (Acts 12:19). the Empire determined the standing of local elites and religious figures, often scripting them as clients of the Empire, which is the ultimate patron. In the end, according to Acts, such military and political figures were like other Gentiles' instruments in God's hands, legitimating a Gentile mission without legitimating Gentile supremacy:

the Gentiles are still understood by Luke to be the means of divine vengeance, but these Gentiles are Israel's enemies probably the Roman armies, and certainly not the gentile Christians. (Tiede 1988:338)

Acts affirms both God's faithfulness, even to a faithless people, and God's vengeance and vindication (cf. Ac 11:17-18; 13:46-47), carried out to a large extent in Acts by political and military characters: the missionary force of God's kingdom overruns the petty postures of the imperial forces (cf. Punt 2015:89-106).

Acts' depiction of the Empire's political and military officials suggests that the hostility Jesus followers experienced did not derive from imperial distrust or discontentment (e.g. Crossan \& Reed 2004:30-32). In short, neither was the church the enemy of Rome nor Rome the enemy of the church; and 'sensible Roman administrators' and 'sensible Christians' knew this (Bryan 2005:105). But Bryan pushes it too far when he claims that NT authors viewed God as holding authorities, such as the Roman Empire, accountable to fulfil the purpose for which God gave them the power (Bryan 2005); this is to privilege a secondary interpretative grid as authoritative framework for perceiving the socio-political dimensions of NT documents. Bryan's conclusion is unlikely, requiring all NT texts to conform to the same norm and obscuring unique features inherent to each; it also fails to reckon with the push and pull of the Empire in the 1st century, the kind of ambivalence typical of hegemonic contexts. For those outside of Jewish circles, the proclamations and actions of Jesus followers may have conjured up notions that could be interpreted as having a political thrust. Already in Acts 16:19-20 this becomes clear, and now again in Acts 17:5-6. Not discounting the possibility that Acts used irony, the new movement's message of transformation is causing disruption.

\section{Accusation 2: Acting against Caesar's decrees}

Although a matter of interpretation, it appears as if the following two accusations of acting against Caesar's decrees and claiming another king, namely Jesus in Acts 17:1-9, filled out the primary accusation of behaving as world disturbers. Be that as it may, a second explicit accusation in the narrative was that Paul, Silas and the others infringed upon, or defied

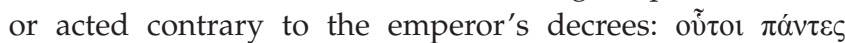

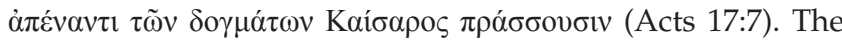
accusation was clearly political, but in this respect our categories become confusing for making good sense of the ancient world.

The modern, conventional separation and even distinction between religion and politics breaks down in the 1st century 
since they 'intertwine to form a coherent pattern of life' (Rowe 2009:7), and conceals the basic similarity between politics and religion, past and present, as 'both are ways of systematically constructing power' (Price 1984:237). ${ }^{26}$ Unlike today's sense of religion as a system of beliefs or impersonal pattern of ritual actions, cult better describes ancient religion: 'those rituals and offerings whereby ancients enacted their respect for and devotion to the deity, and thereby solicited heaven's good will' (Fredriksen 2006:590). Individual households, and at times individuals themselves, practiced their versions of piety, but worship was generally public, communal and political (at civic and imperial levels). ${ }^{27}$ Religion today focusses on inner disposition of believers, 'psychological states' or even 'sincerity of belief'; ancient 'religion' in contrast focussed on acts: 'how one lived, what one did, according to both inherited and local custom. Ancient religion was thus intrinsically communal and public: performance-indexed piety' (Fredriksen 2006:590). ${ }^{28}$ So while Acts provides no information on how imperial decrees were defied, and while these may be trumped-up charges, the narrative can claim credibility largely because Paul and Silas' 'religious' activities in the 1st century would not have stood aloof from 'politics'.

The role of the priestly elite of the Temple in Jerusalem illustrates the intersection of religion, politics and economics. Rome did not expect its conquered subjects to drop their religious affiliations, but to broaden them to accommodate the Roman gods and sense of religiosity or, at least, to tune local cults to show support for the Roman cause (see Carter 2006:66). It was little surprise, then, that the priestly elite generally sided with the Romans when unrest broke out, since their loyalty ensured that they retained their power and privileges. In ways similar to the Roman and Herodian elites, priestly elites obtained wealth through tithes and sacrifices made by people to the Temple. The priestly elite acted as the patrons of God and subjects of the Roman Empire..$^{29}$ Yet, imperial edicts disallowed the prediction, not to mention announcement, of new rulers especially since Roman citizens swore an oath of loyalty to the emperor which then also puts the third accusation against Paul and Silas in perspective.

26.As Galinsky (1996:288) convincingly argued, 'Fundamentally, religion is a response and alternative to chaos; it is an attempt to provide structure, order and meaning, the very efforts that lay at the heart of the Augustan reconstitution of the res publica'. See, for example, also in Sib Or 3.545-555 for religion as mechanism to acculturate and control subject peoples.

27.Recent interpretation of literary and archaeological remains indicate that Roman emperor worship was a public enterprise but that the current emperor was most likely worshipped fairly widely in domestic cults within household contexts. See Gradel (2002:198-212). The value of emperor worship is hard to overestimate, as Gradel (2002:198-212). The value of emperor worship is hard to overestimate, as
Price (1984:248) argued, 'The imperial cult stabilized the religious order of the world'.

28.The presentation of incipient Christianity stressing faith and dogma misrepresents religion in Roman times. Roman religious forms were about actions, performing state and local rituals to appease the gods, even if (as Versnel 2011 points out) ancient religions were not totally devoid of beliefs. If Christianity's emphasis was on faith as action and content, it may have seemed pointless to many, and even as endangering traditional understandings of human relationships with gods.

29.The Jewish elite's attitude towards the Empire may have been the result of a longer period during which non-cultic honours were bestowed upon the Romans in synagogues (e.g. Philo, Flacc 49, Legat 132) and sacrifices made for the emperors in the temple (Josephus, Apion 2.76-77, 409-410, 412-417; already the case for in the temple (Josephus, Apion 2.76-77, 409-410, 412-417; already the case for
Hellenistic rulers, for example, 1 Macc 7:33; Arist 45) - within certain limits and Hellenistic rulers, for example, 1
generally keeping a fine balance.

\section{Accusation 3: Claiming another king}

Depending on one's reading of the participle, the accusation that Paul and Silas proclaimed another king, Jesus, $\beta \alpha \sigma \imath \lambda \dot{\varepsilon} \alpha$

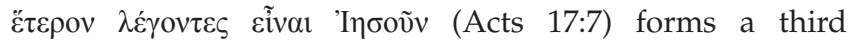
accusation, which constituted a direct assault on the claims of the emperor and the Empire. With the introduction of the princeps early in the Principate, the emperor was not only the supreme ruler but also the intermediary between the gods and the people, and the ultimate (earthly) benefactor. Claiming another king constituted treason and a capital offense. Not only did Romans swear allegiance to the emperor but also pledged to report any possible treason. Although Acts never mentions the emperor cult directly (cf. e.g. Rowe 2005:282), this accusation may be an indirect reference to emperor worship. Moreover, if Paul and Silas did indeed preach about the new ruler's advent as suggested by the first Thessalonians letter, the current emperor's demise was implied. In fact, the charges of sedition against him and the very punishment suffered by Jesus Christ in the form of crucifixion would have rendered further credibility to the claims against his followers (cf. Keener 1993:374).

His insistence on the lordship of Christ yet appealing to Caesar frames Paul's ambiguous relationship with the Empire. ${ }^{30}$ Paul's affirmation of Jesus' lordship in Acts entailed more than the mere use of a title, kv́pıs, for Jesus Christ. Here in Acts 17 in Thessalonica, Paul and Silas are accused of proclaiming a different 'king' (Ac 17:7). ${ }^{31}$ Nevertheless, in Acts, Paul is certainly not alone is his affirmation of Christ as Lord ( $\kappa$ ó politics. In the first chapter of Acts, Jesus is addressed likewise (Ac 1:6), soon confirmed by his ascension ${ }^{32}$ and the proclamation of the 'two men in white robes' (Ac 1:9-11), and dramatically in Peter's Pentecost speech (cf. Ac 2:36ff.).

Paul's adversarial stance to the imperial forces in Acts $^{33}$ did not preclude Roman imperial protection, characterised by Paul's use of the available legal processes. No stranger to political trouble, the accusation that he initiated a riot in Ephesus led to his running away from the town (Ac 19:23-20:1), whereas his involvement in creating a public disturbance in Philippi landed him in jail (Ac 16:16-40). Acts presents a Paul that is conversant with the legal system, and his court appearances saw him defending himself eloquently

30.Avoiding the inexhaustible debates about the historicity of Acts, Acts' portrait of Paul before pagan and Jewish authorities illuminates the reanimation and retrieval Paul before pagan and Jewish authorities illuminates the reanimation and retrieval of Jewish traditions: Pau "is propar prepared to remind the overstep their duty. He uses his own Roman citizenship when it suits the demand of this mission. But at the same time he is fearless in announcing, and living by, a different allegiance' (Wright 2005:70)

31.In this regard, Acts 17:22-31, the well-known Areopagus speech, is also importan for Paul's emphasis on the creator God who calls all people to him, and who will

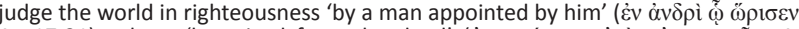

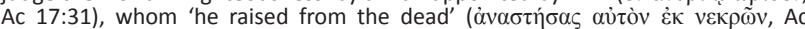
17:31).

32. Roman emperors often used the notion of the ascension of their predecessors' souls to heaven as final proof of the latter's divinity (Wright 2005:64). See also the reference to Gilbert (2003) below.

33. Literally challenging the authorities against all odds, such as in Philippi where he insisted that the magistrates do not send the police ( $\tau$ ov̀c $\dot{\rho} \alpha \beta \delta$ ov́ $\operatorname{lov}_{\mathrm{c}}$ ) but they should come themselves and set Paul and Silas free, Acts 16:37. See Burrus should come themselves and set Paul and Silas free, Acts 16:37. See Burrus
(2007:150-152) on Acts 16 and the contrasting images found in Lydia and the spirit-possessed slave girl in Philippi. 
(Ac 24-25). Avoiding a trial by Jewish leaders which might have led to his summary execution (Ac 25:10-11), Paul knew how to appeal to Caesar. In short, the Acts 17:1-9 account alludes to the ambivalence involved in the inevitable negotiating of the Empire in the 1st century.

\section{Engaging the Empire in Acts}

The ambiguity of the imperial context, and to some extent of Acts' portrayal of Paul, all too often escape the attention of scholars, leading to reductionist portrayals based on simple binaries and neglecting rhetorical clues befitting a 1st-century world. ${ }^{34}$ Simple either-or positions do not hold water:

Luke certainly does not present Paul as a subversive figure; in fact, he is at pains to defend Paul against the charges brought against him as an anti-Roman agitator. Indeed, he portrays him as a Roman citizen who is very much aware of the benefits Rome has bestowed on him. Yet even if one discounts Luke's portrait of Paul as a tendentious piece of propaganda designed to rehabilitate his hero in Roman eyes, we are still confronted by a lack of explicit statements by Paul that could be construed as subversive. (White 2009:305)

The tenuous relationship between text and reality in general, doubts about the historical accuracy of Acts' depictions in particular, and the ever-present lurking danger of the intentional fallacy, means that such a claim does not adequately deal with the socio-historical, imperial context or the rhetorical force of the narrative as such.

Accounting for the Jesus followers-Empire relationship in Acts is neither resolved through appeal to some or other consensus nor is it my argument here. Rather, the Acts 17:1-9 narrative is testimony to the pervasive presence of the Empire in Acts, couched in ambivalence; moreover, it is part of a broader narrative that presents the Empire and Jesus follower communities as countervailing missionary forces ${ }^{35}$ (cf. Punt 2015:89-106). Acts' narrative is at no great pains to set the charges aside even though the rhetoric of the narrative suggests the innocence of Paul and compatriots. Rhetorically, imperial parlance is invoked and appropriated by Acts for the developing narrative of the Jesus followers. ${ }^{36}$ The uneven

34.The role of the Empire in Acts should, of course, be understood in conjunction with the broader message of the document. A brief catalogue of five proposals for the centre of Acts from a theological perspective illustrates not only diversity but also the equalising force of a strongly theological interpretation: salvation, with God as the prominent driver within the narrative. God, portrayed as purposeful (fulfillin the promises) as a mission OT promises), as a missionary God focussing on first Jews then also Gentiles, as God acting through people, and as a saving God; the believing community, complete with positive and negative aspects, Jesus, particularly the message about discussions about the Spirit's role in human empown the Spirit's place in conversion (Walton 2008:76-79).

35.Acknowledging that amidst the various interpretative stances on the relationship between the church and the Empire, other significant issues in Acts such as narratological structure and purpose; historicity, historiography and negotiating identity; genre and relationship to the gospel of Luke are also important but canno be addressed owing to the limitations of the paper. On the setting of Acts, see Bauckham (1995) for a Palestinian, and Gill and Gempf (1994) for a Greco-Roman setting. For a brief debate on how best to deal with introductory matters regardin Luke-Acts, see Spencer (2005:104-124) and Wenham (2005:79-103). See especially the helpful remarks of Spencer (2005:118-121) regarding the tenuous link between textual references and historiographical veracity in the 1st century, expressing care not to claim too much for references such as Claudius' expulsion of the Jews from Rome (Ac 18:2).

36.In the words of Gilbert, 'The imitation of terms and images often associated with Roman power, however, points to a different and more conflicted relationship between the Christianity represented by Luke-Acts and Rome' (Gilbert 2003:254). setting of diverse but rival assertions and ambitions among both the church and the Empire created the breeding ground for the ambiguities that characterised this relationship as presented in Acts. ${ }^{37}$ Acts shows upon the imperial context derived or inscribed - as the prevailing and primary sociopolitical milieu for understanding Jesus in the contemporary urban world.$^{38}$ However, it also shows different angles to the relationship between the kingdom of God and the Roman Empire portrayed as countervailing forces from different perspectives within the narrative, and with ambiguities which Acts was apparently in no hurry to resolve.

The often futile attempts to dissolve the tensions in Acts, frequently by enlisting statistics in support or denigration of the Empire, contribute to the need for a more constructive approach. In fact, it is through the narrative's tensions and strains (Burrus 2007:133-155) that it steadily emerges that two prevailing forces are locked in an intense struggle. Acts shows how totalising claims of one empire (Roman) are opposed with those of another (God's kingdom). ${ }^{39}$ The text's subversiveness is most evident in 'the very ambivalence that earned Luke his reputation as an apologist for Rome' (Burrus 2007:139). Acts affirmed the value of truth and the importance of justice (Ac 21-26), ambivalently, by using the Empire's claims and norms against it, and public transcripts in hegemonic situations against the powerful (Scott 1990:106; cf. Gilbert 2003). At the same time, however, the imperial system is challenged by constant negative portrayal of Roman governors as well as client rulers, as was already the case with Herod in Luke 23 (Burrus 2007:140). ${ }^{40}$

Paul's relationship with the Empire and the related powers in Acts is, to say the least, ambiguous. ${ }^{41}$ On the one hand, Paul holds the coveted Roman citizenship (Ac 16:37; 22:25-29), ${ }^{42}$ came from Tarsus (Ac 21:39; 22:3) and had Pharisaic training (Ac 22:3; 23:6; 26:5). On the other hand, in Acts, Paul at times becomes a revolutionary, falling foul of the law, taking Roman authorities to task and finding himself in political trouble (cf. Hollingshead 1998:xii). The general picture is ambiguous too.

37.This is not to suggest the elimination of Israel's history and traditions as sociocultural interpretative framework for understanding Jesus' significance. To use Wenham's terms, the 'Jewish/Old Testament rootedness of Jesus and the Christian gospel' is evident in Acts (Wenham 2005:92)

38.The narrative of Acts develops within an urban environment, suggested already by the interesting statistic that half of the references to 'city' in the NT are found in Luke-Acts (cf. Rohrbaugh 1991:125).

39.The prevalence of overt Roman propaganda and ideology made it unnecessary for 'Luke to have read Vergil or Horace or to have set foot in the ancient city of Aphrodisias ... Rome's political ideology of universal dominion spread through many channels, making it highly unlikely that Luke, or any resident of the empire, could have avoided exposure to its claims' (Gilbert 2003:255).

40.A first area replete with tension is the role ascribed to Jews amidst the countervailing missionary forces of the church and the Empire - however, space does not allow further discussion here, neither of Acts' Jews nor of the half-truths proclaimed about them. Another area which had to be omitted here because of space constraints concerns socioeconomic matters; although on economical terrain also, the forces of the Empire and the church pulled in different directions, 'Luke's view of economic relations finally presents an even more mixed message than does his view of Roman politics' (Burrus 2007:144).

41.For a brief survey of the portrait of Paul in Acts, see Walton (2004:242-244). Neither the question about correspondence between Paul's portrayals in Acts and his letters nor whether Acts reflects the interpretation of Paul by later generations or traditions can be addressed here.

42.Acts' Paul invoked Roman citizenship claims in political situations, appearing before a Roman proconsul and in the custody of a Roman centurion, respectively. For more on Paul in prison, see Rapske (1994). 
On the one hand, antagonists accused Paul of belonging to the group that turns the world upside down (Ac 17:6). The accusation of 'anarchy' (Walsh 2005:27) comes as no shock, given their leader's politically steeped death, and since the Jesus follower communities existed at the sufferance of the Empire. On the other hand, Paul's virtue is attested repeatedly in Acts when local courts of law acquit him (e.g. Ac 25:8). In the end, however, Paul and Acts' message built upon the resurrection which 'apocalyptically undoes the world', and posed a challenge to the status quo at different levels, causing discontent among the crowd (Ac 17:4-5). 'For Paul, grace is a disruptive miracle. Such miracles do not merely transform chaos into order. First, they transform someone else's world into chaos' (Walsh 2005:27) - and in Acts it is the Roman Empire in its different formats that is often at the receiving end. The final verses of Acts 28:30-31 make it clear which mission in the end prevailed, when Paul during his reported 2-year stay preached Christ in freedom and without hindrance ( $\mu \varepsilon \tau \grave{\alpha} \pi \alpha ́ \sigma \eta \varsigma \pi \alpha \rho \rho \eta \sigma i ́ \alpha \varsigma \dot{\alpha} \kappa \omega \lambda v ́ \tau \omega \varsigma) .{ }^{43}$

In the end, Acts portrays Paul's subversion of the Empire not as quid pro quo actions, matching the emperor and the Empire blow by blow. Rather, Paul reconceptualised Christ's socio-political significance, using the terminology and frameworks of imperial power structures which the Empire may have wanted to retain for its needs. Paul's position remained ambiguous, using such privileges which Roman citizens could rightfully claim, while maintaining Christ's lordship. Ironically, Vaage (2006) argues:

It may be - indeed, I do not doubt - that Paul himself meant to oppose contemporary Roman rule. But precisely because his language of opposition was derived from the discourse of the empire, the long-term legacy of such speech could hardly be anything other than a recurrence of the same. (p. 278)

The push and pull of the Empire, the eventual rub-off of the Empire on those within its realm regardless of their support or opposition against matters imperial, cannot escape the omnipresent tentacles of its hegemony or the resultant ambivalence of life under the Empire.

\section{Conclusion}

The accusations levelled against Paul and Silas in Acts 17:1-9 were all related to the Roman Empire, reflecting both Acts' perspective on the gospel message's impact on life as well as its political reception. Aside from the customary visit to a

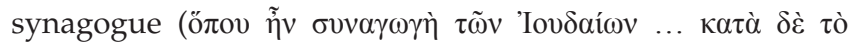

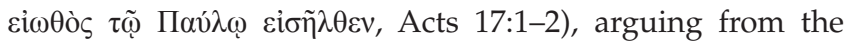

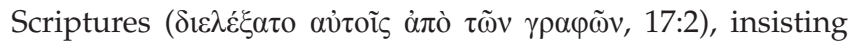

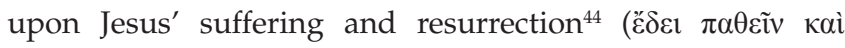

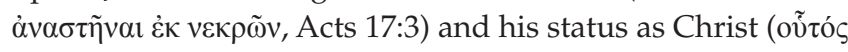

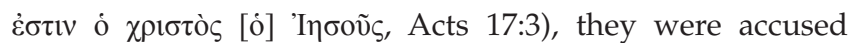
before the local governing authorities of sedition against the

43. П $\alpha \rho \rho \eta{ }^{\prime} \alpha$, often used in politically charged contexts or states of affliction, is suggestive of the situation presented in Acts.

44.Gilbert (2003:242-247) sees the ascension of Jesus as one of three elements (the other being the portrayal of Jesus as bringer of peace, and the list of nations) in Acts taking up and retooling Roman propaganda.
Roman Empire. Acts' framing of the accusations against Paul and Silas as anti-imperial actions given the missionary thrust of their work put the competing missions of the Romans and Jesus followers in Acts in clear relief. Vaage's (2006:254) remark that 'Christianity's eventual emergence as a religion of the empire is an outcome thoroughly consistent with (much of) earliest Christianity's constitutive discourse ${ }^{45}$ and not so obviously a transformation or deviation from its original nature' underlines the ambivalence of NT texts like Acts regarding the Empire, and 1st-century relationships between Jesus communities and reigning discourses and structures of power.

\section{Acknowledgements Competing interests}

The author declares that he has no financial or personal relationships which may have inappropriately influenced him in writing this article.

\section{References}

Alexander, L., 1991, 'Introduction', in L. Alexander (ed.), Images of Empire, pp. 11-18. JSOT Supplementum Series, vol. 112, JSOT, Sheffield.

Bauckham, R. (ed.), 1995, The book of Acts in its Palestinian setting. Book of Acts in its first century setting, vol. 4, Eerdmans, Grand Rapids, MI.

Bryan, C., 2005, Render to Caesar, Jesus, the early Church and the Roman superpower, Oxford University Press, Oxford.

Burrus, V., 2007, 'The Gospel of Luke and the Acts of the Apostles', in F.F. Segovia \& R.S. Sugirtharajah (eds.), A postcolonial commentary on the New Testament writings, The Bible and postcolonialism, vol. 13, pp. 133-155, T \& T Clark, New York.

Carter, W., 2006, The Roman Empire and the New Testament: An essential guide. Abingdon essential guides, Abingdon, Nashville, TN.

Cassidy, R.J., 1978, Jesus, politics, and society: A study of Luke's Gospel, Orbis, Maryknoll, NY.

Cline, E.H. \& Graham, M.W., 2011, Ancient empires. From Mesopotamia to the rise of Islam, Cambridge University Press, Cambridge.

Conzelmann, H., 1960, The theology of St Luke, Faber \& Faber, London.

Crossan, J.D. \& Reed J.L., 2004, In search of Paul. How Jesus's apostle opposed Rome's empire with God's kingdom. A new vision of Paul's words and world, Harper, San Francisco, CA

Dunn, J.D.G., 1993, The Epistle to the Galatians. Black's New Testament commentaries, Hendrickson, Peabody, MA.

Esler, P.F., 1987, Community and Gospel in Luke-Acts: The social and political motivation of Lucan theology, SNTSMS, vol. 57, Cambridge University Press, Cambridge.

Fredriksen, P., 2006, 'Christians in the Roman Empire in the first three centuries CE', in D.S. Potter (ed.), A companion to the Roman Empire. Blackwell companions to the ancient world, pp. 587-606, Blackwell, Malden, MA.

Galinsky, K., 1996, Augustan culture. An interpretive introduction, Princeton University Press, Princeton, NJ.

Gilbert, G., 2003, 'Roman propaganda and Christian identity in the world-view of Luke-Acts', in T. Penner \& C. Vander Stichele (eds.), Contextualizing Acts. Lukan narrative and Greco-Roman discourse, SBL Symposium Series, vol. 20, pp. 233-256, Society of Biblical Literature, Atlanta, GA.

Gill, D.W.J. \& Gempf C. (ed.), 1994, The book of Acts in its Greco-Roman setting. Book of Acts in its first century setting, vol. 2, Eerdmans, Grand Rapids, MI.

Gradel, I., 2002, Emperor worship and Roman religion. Oxford Classical Monographs, Clarendon, Oxford

Hollingshead, J.R., 1998, The household of Caesar and the body of Christ. A political interpretation of the letters from Paul, University Press of America, Lanham.

Keener, C.S., 1993, The IVP Bible background commentary: New Testament, InterVarsity Press, Downers Grove, IL.

Malina, B.J. \& Neyrey, J.H., 1991, 'Conflict in Luke-Acts: Labelling and deviance theory', in J.H. Neyrey (ed.), The social world of Luke-Acts. Models for interpretation, pp. 97-122, Hendrickson, Peabody, MA.

Neagoe, A., 2004, The trial of the Gospel: An apologetic reading of Luke's trial narratives, SNTS Monograph Series, vol. 116, Cambridge University Press, Cambridge.

45.Gilbert (2003:256) concludes his study on Acts' use of Roman-style propaganda 'By echoing and repackaging various forms of Roman propaganda, Luke-Acts provides Christians with their source of legitimization and bolsters the nascent selfidentification of the Christian community in the first and second centuries'. 
Neyrey, J.H., 1991, 'The Symbolic Universe of Luke-Acts: "They turn the world upside down"', in J.H. Neyrey (ed.), The Social World of Luke-Acts. Models for interpretation, pp. 271-304, Hendrickson, Peabody, MA.

Price, S.R.F., 1984, Rituals and power. The Roman imperial cult in Asia minor, Cambridge University Press, Cambridge.

Punt, J., 2013, 'Negotiating creation in imperial times (Rm 8:18-30)', HTS Teologiese Studies/Theological Studies 69(1), Art. \#1276, 8 pages. http://dx.doi.org/10.4102/ hts.v69i1.1276

Punt, J., 2015, Postcolonial biblical interpretation. Reframing Paul. STAR vol. 20, Brill, Leiden.

Quint, D., 1989, 'Epic and Empire', Comparative Literature 41(1), 1-32, viewed 09 March 2011, from http://www.jstor.org/stable/1770677. http://dx.doi.org/10. 2307/1770677

Rapske, B., 1994, The book of Acts and Paul in Roman custody. Book of Acts in its first century setting, vol. 3, Eerdmans, Grand Rapids, MI.

Rohrbaugh, R.L., 1991, 'The pre-industrial city in Luke-Acts: Urban social relations', in J. Neyrey (ed.). The Social World of Luke-Acts. Models for interpretation, pp. 125-149, Hendrickson, Peabody, MA.

Rowe, C.K., 2005, 'Luke-Acts and the imperial cult: A way through the conundrum?', Journal for the Study of the New Testament 27(2), 279-300. http://dx.doi. org/10.1177/0142064X05052507

Rowe, C.K., 2009, World upside down: Reading acts in the Graeco-Roman age, Oxford University Press, Oxford.

Rutledge, S.H., 2001, Imperial inquisitions. Prosecutors and informants from Tiberius to Domitian, Routledge, London.

Scott, J.C., 1990, Domination and the art of resistance. Hidden transcripts, Yale University Press, New Haven, CT.

Seim, T.K., 2004, Double message: Patterns of gender in Luke-Acts, T \& T Clark, London.

Skinner, M., 2015, Intrusive God, disruptive Gospel. Encountering the divine in the book of Acts, Brazos, Grand Rapids, MI.

Smith, M.G., 2010, 'The empire of theory and the empires of history - A review essay', Christian Scholar's Review 39(3), 305-322.
Spencer, F.S., 2005, 'Preparing the way of the Lord: Introducing and interpreting Luke's narrative: A response to David Wenham', in C. Bartholomew, J.B. Green \& A.C. Thiselton (eds.), Reading Luke. Interpretation, reflection, formation. Scripture and Hermeneutics Series, vol. 6, pp. 104-124, Zondervan, Grand Rapids, MI.

Taylor, J., 1994, "Why were the disciples first called "Christians" at Antioch? (Acts 11,26)', Revue Biblique 101(1), 75-94.

Tiede, D.L., 1988, “"Glory to thy people, Israel”: Luke-Acts and the Jews', in J. Neusner, P. Borgen, E.S. Frerichs \& R. Horsley (eds.), The social world of formative Christianity and Judaism. Essays in tribute to Howard Clark Kee, pp. 327-341, Fortress Press, Philadelphia, PA.

Vaage, L.E., 2006, 'Why Christianity succeeded (in) the Roman Empire', in L.E. Vaage (ed.), Religious rivalries in the early Roman Empire and the rise of Christianity, pp. 253-278, Studies in Christianity and Judaism/Études sur le christianisme et le judaïsme, vol. 18, Wilfrid Laurier University Press, Toronto, ON.

Versnel, H.S., 2011, Coping with the Gods: Wayward readings in Greek theology, Religions in the Graeco-Roman World, vol. 173, Brill, Leiden.

Walaskay, P.W., 1983, 'And So We Came to Rome': The political perspective of St Luke. SNTSMS, vol. 49, Cambridge University Press, Cambridge.

Walsh, R., 2005, Finding St Paul in film, T \& T Clark, New York.

Walton, S., 2002, 'The state they were in: Luke's view of the Roman Empire', in P. Oakes (ed.), Rome in the Bible and the early church, pp. 1-41, Paternoster, Carlisle.

Walton, S., 2004, 'Acts. Many questions, many answers', in S. McKnight \& G.R. Osborne (eds.), The face of New Testament studies. A survey of recent research, pp. 229-250, Baker Academic, Grand Rapids, MI.

Walton, S., 2008, 'Acts', in K.J. Vanhoozer, D.J. Treiter \& N.T. Wright (eds.), Theological interpretation of the New Testament. A book-by-book survey, pp. 74-83, SPCK, Grand Rapids, MI.

Wenham, D., 2005, 'The purpose of Luke-Acts: Israel's story in the context of the Roman Empire', in C. Bartholomew, J.B. Green \& A.C. Thiselton (eds.), Reading Luke. Interpretation, reflection, formation, Scripture and Hermeneutics Series, vol. 6, pp. 79-103, Zondervan, Grand Rapids, MI.

White, J. 2009, 'Anti-imperial subtexts in Paul: An attempt at building a firmer foundation', Biblica 90(3), 305-333.

Wright, N.T., 2005, Paul: In fresh perspective, Fortress, Minneapolis, MN. 